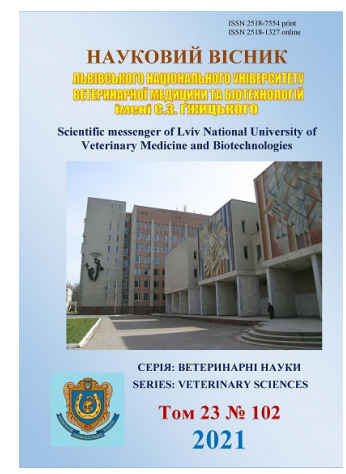

Науковий вісник Яьвівського національного університету ветеринарної медицини та біотехнологій імені С.3. Гжицького. Серія: Ветеринарні науки

\author{
Scientific Messenger of Lviv National University \\ of Veterinary Medicine and Biotechnologies. \\ Series: Veterinary sciences
}

UDC 619:616.995:636.92

\title{
Pathogens of diseases of the digestive tract of rabbits in the parasitocenosis
}

\author{
M. P. Prus ${ }^{1}$, Y. V. Duda ${ }^{2}$ \\ ${ }^{1}$ National University of Life and Environmental Sciences of Ukraine, Kyiv, Ukraine \\ ${ }^{2}$ Dnipro State Agrarian and Economic University, Dnipro, Ukraine
}

Article info

Received 12.04.2021

Received in revised form 13.05.2021

Accepted 14.05.2021

The National University of Life and Environmental Sciences of Ukraine, Heroyiv Oborony Str., 15, Kyiv, 03041, Ukraine.

Dnipro State Agrarian and Economic University, Serhiya Yefremova Str., 25, Dnipro, 49000, Ukraine.

Tel : +38-067-781-54-69

E-mail: dudajulia1976@gmail.com
Prus, M. P., \& Duda, Y. V. (2021). Pathogens of diseases of the digestive tract of rabbits in the parasitocenosis. Scientific Messenger of Lviv National University of Veterinary Medicine and Biotechnologies. Series: Veterinary sciences, 23(102), 93-98. doi: 10.32718/nvlvet10214

Among the causes that cause significant economic damage to the rabbit industry are parasitic and infectious diseases. In different geographical areas, most protozoan and helminthic diseases exist as monoparasitosis and various associations. Associative invasions occur in various combinations. There is not enough information in the literature that could give a complete picture of the current state of infections and invasions of the gastrointestinal tract of rabbits in Ukraine. The aim of our work was to establish the epizootic situation regarding the pathogens of invasive and infectious diseases of the gastrointestinal tract of rabbits. The work was performed during 2019-2020. Monitoring of the epizootic situation regarding parasitosis of the gastrointestinal tract of rabbits was carried out based on the results of coproscopic studies of animals from different regions of Ukraine. The spread of the disease was established by clinical observation, helminthoscopic, helminthovoscopic, helmintholarvoscopic studies of animals and incomplete helminthological autopsy of rabbits aged from birth to 4 years. According to our research, it was found that spirochetosis as a monoinfection was registered in $3.32 \%$ of animals, eimeriosis as a monoinvasion - in $10.70 \%$, passalurosis - in $3.33 \%$, strongyloidosis - in $4.79 \%$, cysticercosis - in $1.85 \%$. Parasitosis of the gastrointestinal tract of rabbits most often occurred in the form of myxinvasions (76.01\%). Most often associative parasitosis of rabbits was detected as part of two-component mixinvasions (54,85\%), less often recorded in the form of three-component mixinvasions $(37.38 \%)$ and four-component mixinvasions (7.77\%). Polyinvasions consisted of associations: prokaryotes, protozoa and nematodes (32.52\%), protozoa and nematodes $(30.10 \%)$, different types of nematodes $(11.17 \%)$, prokaryotes and nematodes $(9.22 \%)$, prokaryotes and protozoa $(6.80 \%)$, protozoa and cestodes $(3.88 \%)$, cestodes and nematodes $(2.91 \%)$, prokaryotes and cestodes (2.43\%), prokaryotes, protozoa, cestodes and nematodes $(0.97 \%)$, protozoa, cestodes and nematodes $(0.49 \%)$. In the parasitocenoses of the gastrointestinal tract of rabbits are most often registered in the form of associations with Eimeria spp. and Treponema cuniculi (19.42\%), Eimeria spp., Passalurus ambiguus and Treponema cuniculi (18.45\%), Eimeria spp., Treponema cuniculi and Strongyloides papillosus (13.11\%), Passalurus ambiguus and Strongyloides papillosus (11.17\%). In total, 11 combinations of different types of parasites were identified, the co-members of which are passalurus, 10 - eimeria, 7 -strongyloides and treponema, 6-cysticercus.

Key words: Eimeria spp., Passalurus ambiguus, Treponema cuniculi, Strongyloides papillosus, parasitocenosis, associative parasitosis, rabbits.

\section{Збудники хвороб травного каналу кролів у складі паразитоценозів}

\author{
М. П. Прус ${ }^{1}$, Ю. В. Дуда ${ }^{2}$ \\ ${ }^{1}$ Національний університет біоресурсів і природокористування України, м. Київ, Украӥна \\ ${ }^{2}$ Дніпровський державний аграрно-економічний університет, м. Дніпро, Украӥна
}

Серед причин, які завдають значних економічних збитків галузі кролівнищтва, є паразитарні і інфекиійні хвороби. У різних географічних зонах більщість протозойних і гельмінтозних захворювань існують як монопаразитози, так $і$ різні асоціації. Асоціатив- 
ні інвазії зустрічаються в різних комбінаціях. У літературних джерелах недостатньо інформації, яка могла б дати повну картину щзодо сучасного стану інфекцій та інвазій травного каналу кролів на території Украӥни. Метою нашої роботи було встановити епізоотичну ситуацію щчодо збудників інвазійних та інфекційних хвороб травного каналу кролів. Робота виконувалась упродовж 2019-2020рр. Моніторинг епізоотичної ситуації щуодо паразитозів травного каналу кролів проводився за результатами копроскопічних досліджень тварин із різних областей Украӥни. Почирення хвороб встановлювали шляхом клінічного спостереження, гельмінтоскопічних, гельмінтоовоскопічних, гельмінтолярвоскопічних досліджень тварин та неповного гельмінтологічного розтину тушок кролів віком від народження до 4 років. За результатами проведених нами досліджень встановлено, щзо спірохетоз як моноінфекцію реєстрували у 3,32\% тварин, еймеріоз як моноінвазію - у 10,70 \%, пасалуроз - у 3,33 \%, стронгілоїдоз - у 4,79 \%, цистицеркоз пізиформний - у 1,85 \%. Паразитози травного каналу кролів найчастіше зустрічались у вигляді міксінвазій (76,01 \%). Найчастіше асоціативні паразитози кролів виявляли у складі двохкомпонентних міксінвазій (54,85 \%), рідше реєстрували у вигляді трьохкомпонентних міксінвазій (37,38 \%) та чотирьохкомпонентних міксінвазій (7,77 \%). Поліінвазії складались з асоціацій: прокаріотів, найпростіших та нематод (32,52 \%), найпростіших та нематод (30,10\%), різних видів нематод (11,17 \%), прокаріотів та нематод (9,22\%), прокаріотів та найпростіших (6,80\%), найпростіших та цестод (3,88 \%), цестод та нематод (2,91\%), прокаріотів та цестод (2,43\%), прокаріотів, найпростіших, иестод та нематод (0,97 \%), найпростіших, иестод та нематод (0,49\%). У складі паразитоценозів травного каналу кролів найчастіше реєструються у вигляді асоиіацій із Еітегіа sрр. ma Treponema cuniculi (19,42 \%), Eimeria spp., Passalurus ambiguus ma Treponema cuniculi (18,45 \%), Eimeria spp., Treponema cuniculi ma Strongyloides papillosus (13,11\%), Passalurus ambiguus та Strongyloides papillosиs (11,17\%). Загалом виділено 11 комбінацій різних видів паразитів, співчленами яких є пасалуріси, 10 -еймерії, 7 -стронгілоїдеси та трепонеми, 6 - цистицерки.

Ключові слова: Eimeria spp., Passalurus ambiguиs, Treponema cuniculi, Strongyloides papillosus, паразитоценоз, асочіативні паразитози, кролі.

\section{Вступ}

За декілька останніх років в Україні зросла кількість поголів'я кролів, у тому числі за рахунок завезених $з$ інших країн. Серед причин, що стримують розвиток галузі кролівництва - паразитарні та інфекційні хвороби, які набули широкого поширення та завдають значних економічних збитків. Проводячи аналіз літературних джерел останніх десятирічь, можемо сказати, що у різних географічних зонах більшість протозойних і гельмінтозних захворювань існують як монопаразитози, так і різні асоціації (Espindola et al., 2000; Bohach \& Trofimov, 2007; Haliullina, 2009; Dovgij et al., 2014; Duda et al., 2017; Eftenjuk et al., 2017; Duda, 2019).

У світі поширеними захворюваннями кролів $\epsilon$ iнвазійні хвороби органів травлення, екстенсивність інвазії яких, в окремих випадках, може сягати $100 \%$, про що вказують роботи, виконані в Україні (Rudenko, 2007; Lesyk, 2008; Franchuk, 2010; Kotsiubenko, 2013; Novitska \& Semenko, 2015; Duda et al., 2017; Duda et al., 2019), Болгарії та Угорщині (Varga et al., 1995), Єгипті (Eltohamy \& Eldeghedy, 1985), Туреччині (Cam et al., 2006), Великій Британії (Lodge, 1985), США (Coudert, 2004), Кубі (Percedo \& Abeledo, 1985), Індії (Bhat \& Jithendran, 1995), Танзанії (Kambarage, 1997), Китаї (Huan et al., 1997). Асоціативні інвазії найбільш часто зустрічаються в комбінаціях “еймеріоз+пасалуроз” (у $22,7 \%$ кролів), “еймеріоз+пасалуроз+цистицеркоз пізиформний” (у 4,9 \% кролів) і навіть у 0,45 \% кролів була комбінація "еймеріоз+пасалуроз+цистицеркоз+ фасціольоз” (Gerasimchik, 2011). В спеціалізованих господарствах, при закритій системі утримання в клітках, виявили лише еймеріозно-пасалурозну інвазію у 11,11 \% досліджених кролів (Levytska, 2011). У кролів 2-3-місячного віку сформувався паразитоценоз травного каналу, до якого входили еймерії, нематоди підрядів: Strongylata (EI = 20 \%), Oxyurata $(\mathrm{EI}=13 \%)$ та Trychocephalata $(\mathrm{EI}=6,6 \%)$ і $\quad$ один вид T.retortaformis. У 5-6-місячних та старших за віком кролів інвазованість еймеріями досягла 33,3 \% та $10,5 \%$, T. retortaformis - $83 \%$ та 52,6 \%, Passalurus ambiguus $-66,6 \%$ та $42 \%$ та T. leporis $-50 \%$ та $26 \%$ відповідно (Eftenjuk et al., 2017). В період з 2003 по 2012 роки в Інституті паразитології Ганноверського університету ветеринарної медицини (Німеччина), зразки фекалій кролів містили яйця Passalurus ambiguus (3,0 \%), стронгілят (1,8\%) і Trichuris leporis (0,2 \%), а також ооцисти Eimeria (21,2 \%) (Raue et al., 2017). При дослідженні фекалій від кролів 320 господарств індустріального типу Італії виявлено вісім видів еймерій. Показник екстенсивності інвазії при цьому становив $80 \%$, а змішаної еймеріознопасалурозної - 34,6 \% (Hollands, 1994). 3 регіонів Нагпур і Акола (Індія) були досліджені проби фекалій кролів різної вікової групи (1-4 роки). Дослідження зразків фекалій виявило наявність змішаної інвазії таких паразитів, як Giardia spp. (19,04\%), Trichostrongylus spp. $(28,57 \%)$, Graphidium spp. $(19,04 \%)$, Coccidia spp. (16,66 \%) i Passalurus spp. (14,28\%) (Rewatkar et al., 2013).

Слід зазначити, що на сьогодення у літературних джерелах недостатньо інформації, яка могла б дати повну картину щодо ураженості кролів паразитозами травного каналу на території України. Тому проведені нами дослідження є актуальними.

Метою роботи було встановити епізоотичну ситуацію щодо збудників інвазійних та деяких інфекційних хвороб травного каналу кролів.

\section{Матеріал і методи досліджень}

Робота виконувалась упродовж 2019-2020 pp. Моніторинг епізоотичної ситуації щодо паразитозів травного каналу кролів проводився за результатами копроскопічних досліджень кролів із різних областей України. Поширення хвороб встановлювали шляхом клінічного спостереження, гельмінтоскопічних, гельмінтоовоскопічних, гельмінтолярвоскопічних досліджень тварин віком від народження до 4 років та неповного гельмінтологічного розтину тушок кролів.

Лабораторні дослідження проводили в лабораторіях кафедри паразитології та ветсанекспертизи 
Дніпровського державного агроекономічного університету.

Для виявлення Treponema cuniculi застосовували метод темнопольної мікроскопії: відібраний матеріал досліджують під мікроскопом, користуючись конденсором темного поля. Дослідження проб фекалій на наявність яєць Passalurus ambiguus та Strongyloides papillosus та ооцист Eimeria spp. проводили флотаційним методом за Г. О. Котельниковим i В. М. Хрєновим (Ponomar et al., 2015). Для з'ясування видового складу яєць гельмінтів кролів Passalurus ambiguus та Strongyloides papillosus, врахувуючи їх морфологічні характеристики та метричні параметри, здійснювали за допомогою атласів диференціальної діагностики гельмінтозів А. А. Черепанова (1999), I. C. Дахна та ін. (2001) (Cherepanov et al., 2001; Dahno et al., 2011). 3 метою ідентифікації яєць Strongyloides papillosus проводили їх культивування (Ponomar et al., 2015), а ооцист роду Eimeria доводили на підставі їх розмірів і морфологічних характеристик (El-Shahawi et al., 2011; Elshahawy \& Elgoniemy, 2018). Cysticercus pisiformis виявляли за допомогою неповного гельмінтологічного розтину тушок кролів, оглядаючи поперекову та тазову частини прямої кишки, брижу, сальник, очеревину, плевру та печінку (Ponomar et al., 2015). Всього проведено 1317 гельмінтологічних розтинів.

При роботі 3 тваринами дотримувалися вимог “Свропейської конвенції щодо захисту хребетних тварин, які використовуються в експерименті та інших наукових цілях" (Страсбург, 18.03.1986 р.). Статистичну обробку експериментальних результатів для визначення біометричних показників (середні значення та їх похибки, порівняння середніх значень за критерієм Стьюдента) здійснювали 3 використанням програми Microsoft Excel-16.

\section{Результати та їх обговорення}

За результатами проведених нами досліджень встановлено, що як моноінфекцію спірохетоз реєстрували у 3,32 \% кролів, еймеріоз як моноінвазію - у $10,70 \%$, пасалуроз - у 3,33\%, стронгілоїдоз - у $4,79 \%$, цистицеркоз - у 1,85\%. Паразитози найчастіше реєструвалися у вигляді міксінвазій за участі збудників різних заразних хвороб. Зокрема, з числа паразитозів травного каналу кролів 76,01 \% становили асоціативні хвороби (рис. 1).

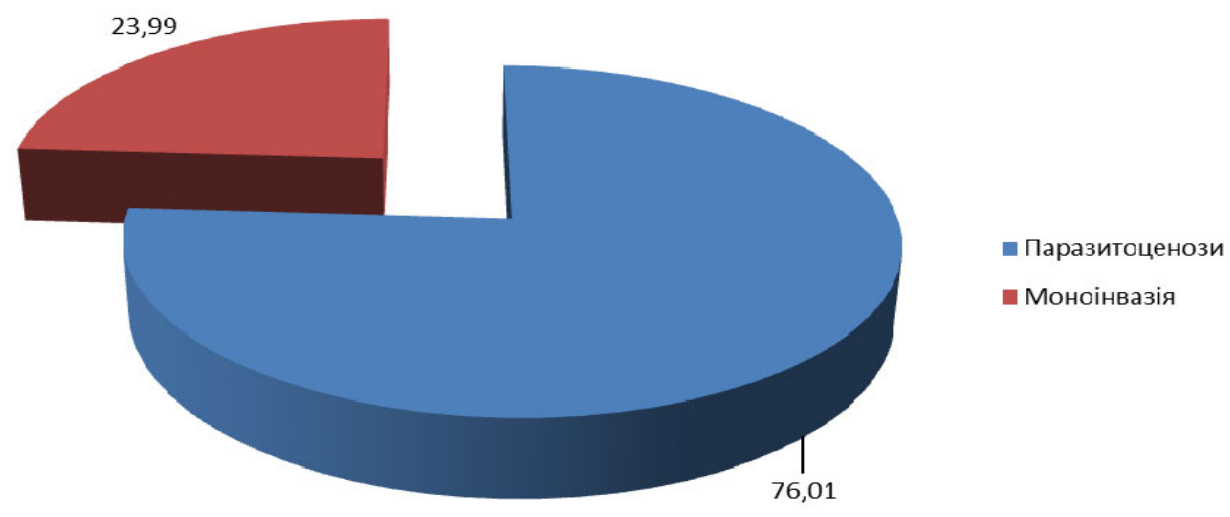

Рис. 1. Співвідношення паразитоценозів до моноінвазії у травному каналі кролів (\%)

За змішаного перебігу хвороб у фекаліях досліджених 1209 кролів виявляли яйця Passalurus ambiguus, Strongyloides papillosus, ооцисти Eimeria spp., збудників Treponema cuniculi, а за неповного гельмінтологічного розтину 223 тушок - Cysticercus pisiformis.
За результатами досліджень виявили 17 видових асоціацій, які були різними за своїми складовими - 2-, 3- та 4-компонентними. Найчастіше асоціативні паразитози кролів виявляли у складі двохкомпонентних міксінвазій $(54,85 \%)$, рідше реєстрували - у вигляді трьохкомпонентних міксінвазій $(37,38 \%)$ та чотирьохкомпонентних міксінвазій $(7,77$ \%) (рис. 2).

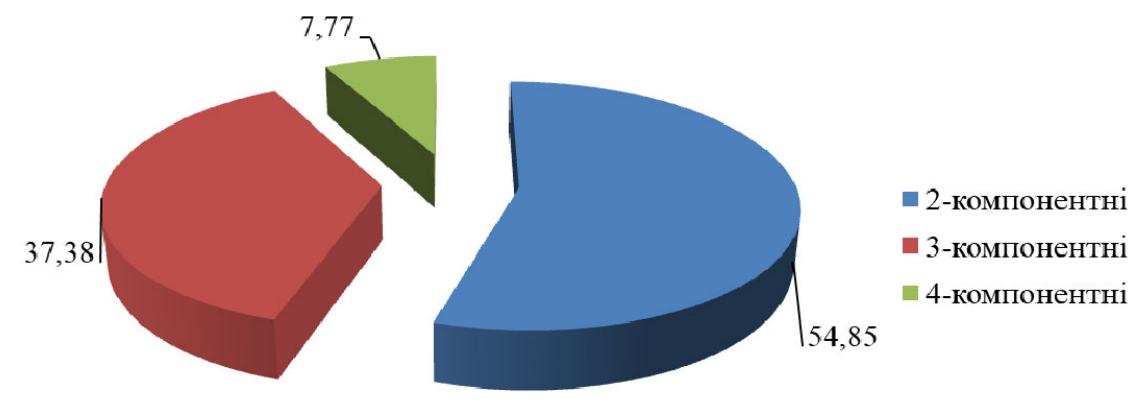

Рис. 2. Відсоткове співвідношення форм перебігу паразитоценозів травного каналу кролів, \% 
Поліінвазії складались 3 асоціацій: прокаріотів, найпростіших та нематод (32,52 \%), найпростіших та нематод (30,10\%), різних видів нематод $(11,17 \%)$, прокаріотів та нематод $(9,22 \%)$, прокаріотів та найпростіших $(6,80 \%)$, найпростіших та цестод $(3,88 \%)$, цестод та нематод $(2,91 \%)$, прокаріотів та цестод (2,43\%), прокаріотів, найпростіших, цестод та нематод $(0,97 \%)$, найпростіших, цестод та нематод $(0,49 \%)$.

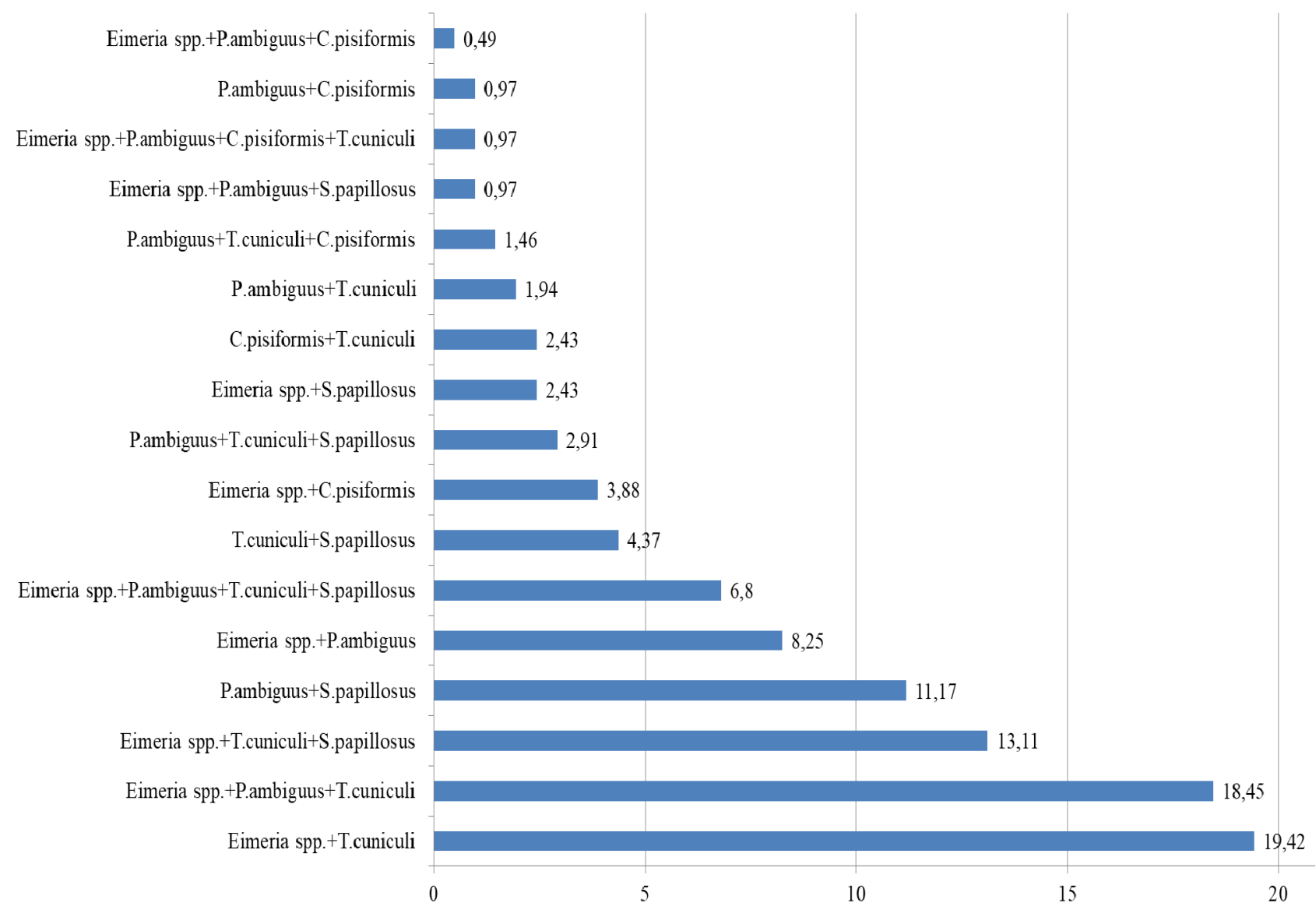

Рис. 3. Збудники хвороб травного каналу кролів у складі паразитоценозів, \%

Нами встановлено, що в паразитоценозах травного каналу кролів найбільший відсоток склали такі компоненти, як: еймеріозно-спірохетозна $(19,42 \%)$, еймеріозно-пасалурозно-спірохетозна $(18,45 \%)$, еймеріозно-спірохетозно-стронгілоїдозна $(13,11 \%)$, пасалурозно-стронгілоїдозна $(11,17 \%)$ (рис. 3$)$. Рідше виявляли наявність асоціації збудників Eimeria spp., Passalurus ambiguus, Treponema cuniculi та Strongyloides papillosus $(8,25 \%)$, Eimeria spp. та Treponema cuniculi $(6,80 \%)$, Treponema cuniculi та Strongyloides papillosus (4,37\%), Eimeria spp. та Cysticercus pisiformis (3,88\%) та інші, відсоток яких складав від 2,91 до 0,49. Загалом виділено 11 комбінацій різних видів збудників, співчленами яких є пасалуріси, 10 - еймерії, 7 - стронгілоїдеси та трепонеми, 6 - цистицерки.

Таким чином, отримані результати свідчать, що збудників асоціативних хвороб травного каналу виявляли у 76,01 \% досліджених кролів. У складі паразитоценозів найчастіше реєструються асоціацій Eimeria spp. та Treponema cuniculi (19,42 \%) Основними у встановлених паразитоценозів $є$ пасалуріси та еймерії. Це співпадає з даними інших дослідників, які виявили в приватному секторі 35,94 \% кролів, хворих на ейме- ріоз та пасалуроз, 19,64 \% - еймеріоз та цистицеркоз, та 15,38 \% - еймеріоз і трихуроз (Levytska, 2011).

\section{Висновки}

Паразитози травного каналу кролів в Україні значно поширені, а їх епізоотичний стан має деякі особливості, що пов'язані, ймовірно, із впливом навколишнього середовища як на макроорганізм, так і на збудників. При цьому, у 76,01 \% досліджених кролів виявляли паразитоценози травного каналу, основними співчленами яких є пасалуріси та еймерії. Найчастіше асоціативні паразитози виявляли у складі двохкомпонентних міксінвазій. Із паразитоценозів шлунковокишкового каналу кролів найбільший відсоток склали збудники еймеріозу+спірохетозу.

Перспективи подальших досліджень. Вивчення вікової динаміки показників інвазованості кролів за паразитозів травного каналу.

Відомості про конфлікт інтересів. Автори стверджують про відсутність конфлікту інтересів щодо їх вкладу та результатів наукових досліджень. 


\section{References}

Bhat, T. K., \& Jithendran, K. P. (1995). Eimeria magna: the effect of varying inoculum size on the course of infection in Angora rabbits. World Rabbit Sc., 3(4), 163-165. URL: $\quad$ https://polipapers.upv.es/index.php/wrs/article/ view/257/244.

Bohach, M. V., \& Trofimov, M. M. (2007). Invaziini khvoroby systemy travlennia kroliv $\mathrm{v}$ hospodarstvakh Odeskoi oblasti. Ahrarnyi visnyk Prychornomoria: zbirn. nauk. pr. Odesa, 39, 96-99 (in Ukrainian).

Cam, Y., Cetin, E., Ica, A., \& Atalay, O. (2006). Evaluation of Some Coagulation Parameters in Hepatic Coccidiosis Experimental Induced with Eimeria stiedai in Rabbits. Journal of Veterinary Medicine Series B, 53(4), 201202. doi: 10.1111/j.1439-0450.2006.00938.x.

Cherepanov, A. A., Moskvin, A. S., Kotel'nikov, G. A., \& Hrenov, V. M. (2001). Differencial'naja diagnostika gel'mintozov po morfologicheskoj strukture jaic i lichinok vozbuditelej: atlas. M.: Kolos (in Russian).

Coudert, P. (2004). Evalution of the efficacy of Cycostat $66 \mathrm{G}$ against coccidiosis in fattening rabbit under controlled field conditions. 8th World Rabbit Congress: Proceedings (September, 7-10, 2004, Puebla, Mexico). World Rabbit Sci.: Abstracts of the pathology and hygiene, 14, 512-519. URL: http://world-rabbitscience.com/WRSA-Proceedings/Congress-2004Puebla/Papers/Pathology/P-Coudert-1.pdf.

Dahno, I. S., Berezovs'kyj, A. V., Galat, V. F., Aranchij, S. V., Jevstafjeva, V. O., Dahno, G. P., Pryhod'ko, Ju. O. (2011). Atlas gel'mintiv tvaryn. K.: Vetinform (in Ukrainian).

Dovgij, J. J., Kushnirova, A. A., Korjachkov, V. A., \& Dovgij, M. J. (2014). Rasprostranenie jejmerioza kur, krolikov, nutrij i metody lechenija. Uchenye Zapiski uchrezhdenija obrazovanija Vitebskoj ordena "Znak pocheta" gosudarstvennoj akademii veterinarnoj mediciny, 50(2), 74-76. URL: https:/www.elibrary.ru/ item.asp? $\mathrm{id}=22531397$ (in Russian).

Duda, Y. V. (2019). Klitynnyi imunitet kroliv za vplyvu asotsiatsii parazytiv (Treponema cuniculi i Eimeria sp.) Naukovyi visnyk Lvivskoho natsionalnoho universytetu veterynarnoi medytsyny ta biotekhnolohii imeni S. Z. Gzhytskoho. Seriia: Veterynarni nauky, 21(96), 8-13. doi: 10.32718/nvlvet9602 (in Ukrainian).

Duda, Y. V. (2019). Nespetsyfichna rezystentnist orhanizmu kroliv za vplyvu asotsiatsii zbudnykiv Treponema cuniculi ta Eimeria sp. Veterynariia, tekhnolohii tvarynnytstva ta pryrodokorystuvannia, 4, 50-54. doi: 10.31890/vtt:2019.04.10 (in Ukrainian).

Duda, Y. V., Kunieva, L. V., \& Khrystian, O. P. (2017). Pokaznyky bilkovoho obminu kroliv za pasaluroznoi invazii. NTB NDTs biobezpeky ta ekolohichnoho kontroliu resursiv APK, 5(1), 93-96. URL: https://bulletin-biosafety.com/index.php/journal/article/view/ 87 (in Ukrainian).

Duda, Y. V., Shevchyk, R. S., \& Kunieva, L. V. (2019). Vplyv Passalurus ambiguus ta Cysticercus pisiformisna na vykhid produktiv zaboiu kroliv Ahrarnyi visnyk Prychornomoria. Veterynarni nauky, 93, 234-239.
URL: https://dspace.dsau.dp.ua/jspui/handle/123456789/ 2869 (in Ukrainian).

Eftenjuk, J., Karaman, M., \& Moskalik, R. (2017). Formirovanie parazitocenoza pishhevaritel'nogo trakta krolikov i vlijanie na jetot process himiopreparatov. In: Actual problems of zoology and parasitology: achievements and prospects. Chișinău. Chișinău, Republica Moldova: Institutul de Zoologie, 251-256. URL: https://ibn.idsi.md/sites/default/files/imag_file/ 251-256_0.pdf (in Russian).

El-Shahawi, G., El-Fayomi, H. M., \& Abdel-Haleem, H. (2011). Coccidiosis of domestic rabbit (Oryctolagus cuniculus) in Egypt: light microscopic study. Parasitology Research, 110(1), 251-258. doi: 10.1007/s00436-011-2479-0.

Elshahawy, I., \& Elgoniemy, A. (2018). An epidemiological study on endoparasites of domestic rabbits (Oryctolagus cuniculus) in Egypt with special reference to their health impact. Sains Malaysiana, 47(1), 9-18. doi: 10.17576/jsm-2018-4701-02.

Eltohamy, M., \& Eldeghedy, N. (1985). Biochemical and physiological changes in the rabbits due to coccidial infection. Indian J. anim. Sc., 55(6), 395-397.

Espindola, N. M., De Gaspari, E. N., Nakamura, P. M., \& Vaz, A. J. (2000). Cross-reactivity of anti-taenia crassiceps cysticerci immune Taenia pisiformis antigens. Vet. Parasitol, 89(4), 321-326. doi: 10.1016/s03044017(00)00208-9.

Franchuk, L. O. (2010). Poshyrennia ta formy perebihu zmishanoi eimerioznoi invazii u kroliv. Ahrarnyi visnyk Prychornomoria. Veterynarni nauky, 56, 148-153 (in Ukrainian).

Gerasimchik, V. A. (2011). Infekcionnye i nezaraznye bolezni pushnyh zverej i krolikov. Vitebsk: VGAVM, 142-145 (in Russian).

Haliullina, O. H. (2009). Veterinarno-sanitarnaja harakteristika mjasa krolikov pri immunodeficite na fone mono- i poliinvazii. $\mathrm{PhD}$ [thesis]. Ufa (in Russian).

Hollands, I. (1994). Observaciones en la passalurosis del coneyo domestico. Rev. cub. Cienc. Veter., 15(3-4), 271-276.

Huan, L., Ruiping, S., \& Junxia, S. (1997). Quantitative analysis of intraepithelial lymphocytes and goblet cells of sacculus rotundus of rabbits infected experimenthly with coccidiosis. Acta veter. zootechn. sinica., 28(5), 448-452.

Kambarage, D. M. (1997). Coccidiosis in caged rabbits. Bull. anim. Health Product. in Africa, 45(4), 261-263.

Kotsiubenko, H. A. (2013). Naukovo-praktychni metody pidvyshchennia produktyvnosti kroliv: monohrafiia. Mykolaiv: MNAU (in Ukrainian).

Lesyk, Y. V. (2008). Fizioloho-biokhimichni protsesy v orhanizmi i produktyvnist kroliv zalezhno vid umov hodivli ta utrymannia. $\mathrm{PhD}$ [thesis]. Lviv (in Ukrainian).

Levytska, V. A. (2011). Epizootolohiia zmishanoi eimerioznoi invazii kroliv v zoni Podillia. Naukovyi visnyk Lvivskoho natsionalnoho universytetu veterynarnoi medytsyny ta biotekhnolohii im. S. Z. Hzhytskoho, 13(4(50), 209-211 (in Ukrainian).

Lodge, N. J. (1985). The safe ionophore anticococcidial. Feed Comrounder, 5(2), 20-25. 
Novitska, O. V., \& Semenko, O. V. (2015). Zarazni khvoroby kroliv. Kiyiv: TOV NVP "Interservis" (in Ukrainian).

Percedo, M. I., \& Abeledo, M. A. (1985). Enteritis del cone y su repercucion en crianzas comerciales en Cuba. Rev. Salud anim, 7(3), 317-322.

Ponomar, S. I., Soroka, N. M., Nebeshhuk, O. D., Goncharenko, V. P., Semenko, O. V., \& Ponomar, Z. S. (2015). Dovidnyk z vyznachennja gel'mintiv tvaryn. Bila Cerkva: TOV “Ofset” (in Ukrainian).

Raue, K., Heuer, L., Böhm, C., Wolken, S., Epe, C., \& Strube, C. (2017). 10-year parasitological examination results (2003 to 2012) of faecal samples from horses, ruminants, pigs, dogs, cats, rabbits and hedgehogs. Parasitol Res., 116(12), 3315-3330. doi: 10.1007/s00436-017-5646-0.
Rewatkar, S. G., Deshmukh, S. S., Prem Kumar, G., Maske, D. K., \& Bhangale, G. N. (2013). Occurrence of gastrointestinal helminthes in rabbits with specialreference to importance of Giardia sp: as parasitic zoonoses. Science, Technology and Arts Research Journal, 2(3), 142-143. doi: 10.4314/star.v2i3.98754.

Rudenko, A. A. (2007). Poshyrennia, biolohichni osoblyvosti zbudnyka ta udoskonalennia profilaktyky pasterelozu krolykiv. $\mathrm{PhD}$ [thesis]. Kharkiv (in Ukrainian).

Varga, I., Papp, Z., \& Gyenes J. (1995). Az Esbsb (3) nyulak epeer-cjccidiosisa elleni hatekoeysaganak vizgalata. Pract. Tierarzt, 76(3), 250-256. 